\title{
HYDROCARBON BIOCOMPONENTS USE IN AVIATION FUELS - PRELIMINARY ANALYSIS OF ISSUES
}

\section{BIOKOMPONENTY WĘGLOWODOROWE DO ZASTOSOWAŃ W PALIWACH LOTNICZYCH - WSTĘPNA ANALIZA ZAGADNIENIA}

\author{
Bartosz Gawron, Urszula Kaźmierczak \\ Instytut Techniczny Wojsk Lotniczych \\ e-mail: bartosz.gawron@itwl.pl,urszula.kazmierczak@itwl.pl
}

\begin{abstract}
Article is related to the aspect of the introduction of biofuels to power turbine aircraft engines. The paper presents the current trends in the use of alternative fuels in aviation and the problems connected with the introduction of hydrocarbon biocomponents. It is pointed to the need to take research and implementation works in the field of the subject, also in Poland.
\end{abstract}

Keywords: fuels, aircraft industry, biocomponents.

Streszczenie: Treść artykutu zwiazana jest z aspektem wprowadzenia biopaliw do zasilania turbinowych silników lotniczych. Przedstawiono aktualne trendy dotyczace stosowania paliw alternatywnych $w$ lotnictwie oraz problematyke zwiazana $z$ wprowadzaniem biokomponentów węglowodorowych. Wskazano również na potrzebę podjęcia prac badawczo-wdrożeniowych $w$ zakresie tej tematyki, również $i$ w Polsce.

Stowa kluczowe: paliwa, przemyst lotniczy, biokomponenty. 


\section{Wprowadzenie}

Aktywność UE w realizacji idei zrównoważonego rozwoju i troska o środowisko naturalne znajduje odzwierciedlenie w ustanawianych przez Parlament Europejski i Radę Europy dyrektywach. Za podstawowe działanie przyjęto identyfikację jakościową i ilościową źródeł emisji zanieczyszczeń do środowiska. Już pierwszy, inicjowany w połowie lat 90-tych przez UE program badawczy EPFE miał na celu identyfikację źródeł zanieczyszczenia powietrza w aglomeracjach miejskich przez transport samochodowy i wskazanie obszarów, w których podjęte działania dadzą największe rezultaty. Kolejne działania, będące rezultatem szczytu klimatycznego i protokołu z Kioto skłoniły UE do szczególnej aktywności w redukowaniu emisji gazów cieplarnianych, w tym głównie $\mathrm{CO}_{2}$. W pierwszym rzędzie zidentyfikowano źródła emisji gazów cieplarnianych (GHG). Na Rys. 1 przedstawiono [8] dane z 2007 r. dotyczące całkowitego poziomu emisji gazów cieplarnianych w 27 państwach członkowskich Unii Europejskiej, w podziale na sektory gospodarki.

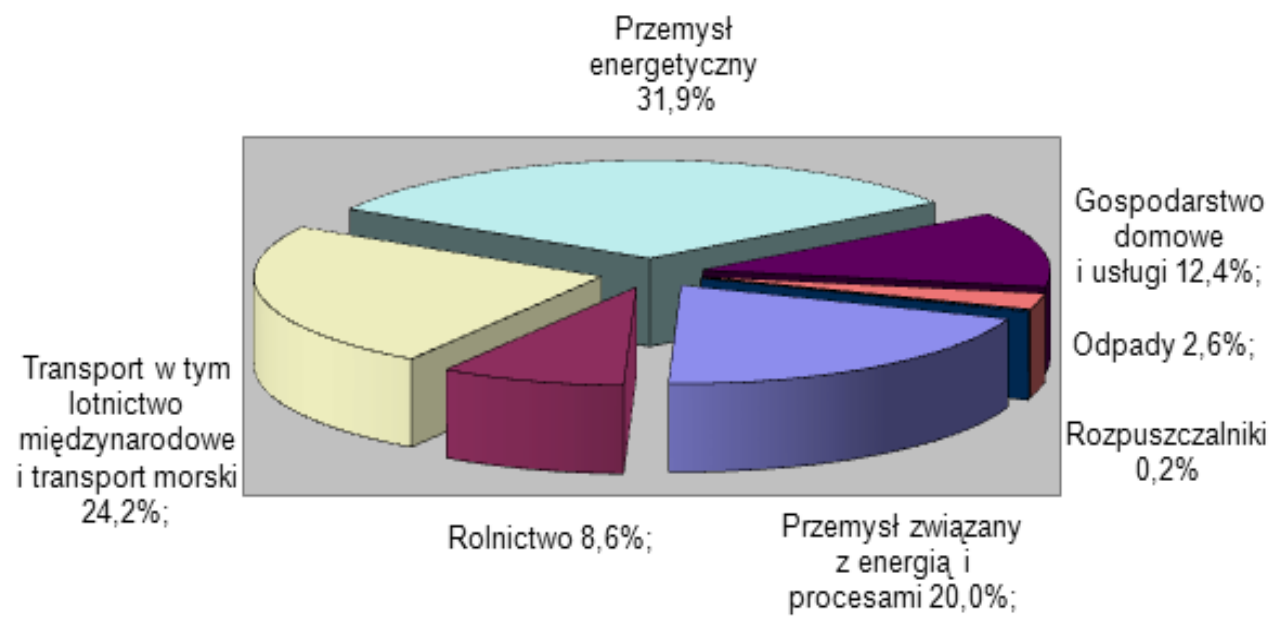

Rys. 1 Emisja gazów cieplarnianych w 27 państwach członkowskich Unii Europejskiej, w podziale na sektory gospodarki

W sektorze transportu za emisję GHG w największym stopniu odpowiada transport samochodowy, na drugim miejscu jest transport lotniczy (Rys. 2.)

Sytuacja przedstawiona na Rys. 2 jednoznacznie wyjaśnia dlaczego główna aktywność UE skupiła się na transporcie samochodowym. Już w końcu lat 90-tych pojawiła się Dyrektywa 98/70 określająca wymagania środowiskowe stawiane benzynom samochodowym i olejowi napędowemu. Pojawiły się również dyrektywy regulujące dopuszczalny skład spalin z silników o zapłonie iskrowym i o zapłonie samoczynnym. 


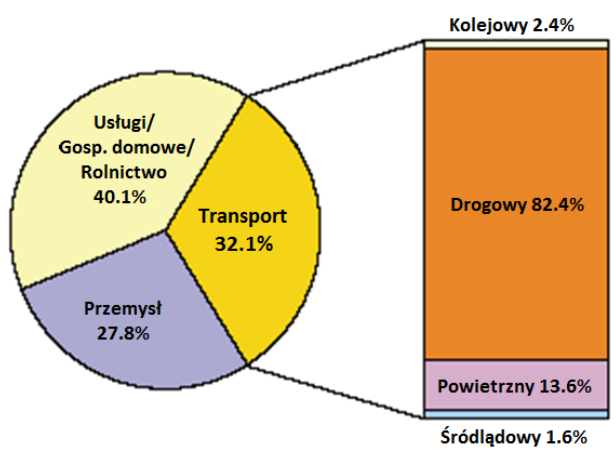

Konsumpcja energii

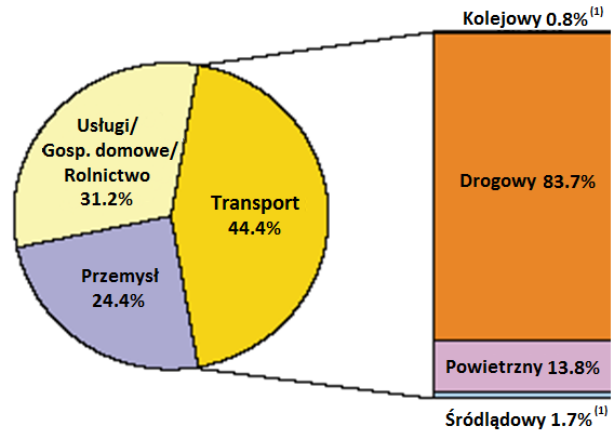

Emisja GHG

Rys. 2 Udziat transportu w emisji gazów cieplarnianych

Rozwój konstrukcji silników samochodowych, jak również technologii przerobu ropy naftowej pozwalał stopniowo zaostrzać wymagania ekologiczne stawiane paliwom; dyrektywa 98/70 została zmodyfikowana w 2003 r., a ostatnio w 2009 r. Komunikat Komisji Europejskiej w sprawie planu utworzenia jednolitego europejskiego obszaru transportu [4] mówi w punkcie 7, że mimo znacznego postępu technicznego oraz potencjału $\mathrm{w}$ zakresie oszczędnych pod względem kosztów i energii rozwiązań i działań politycznych, system transportowy praktycznie się nie zmienił. Ze względu na to, że planowanie, budowa i wyposażenie infrastruktury trwa latami, zaś pociągi, samoloty i statki są wykorzystywane przez dziesięciolecia, podejmowane obecnie wybory będą decydować o transporcie w 2050 r. Rozwiązanie powyższych problemów oznacza, że do 2050 r. zrealizowane zostaną bardzo trudne cele, zaś do lat 2020/2030 ambitne cele pozwalające na zapewnienie właściwego kierunku działań. Wizja Komisji dotyczy trzech głównych segmentów sektora: transportu na średnie odległości, dalekie odległości i transportu miejskiego. W drugiej części dokumentu, pt.: Innowacje z myślą o przyszłości: technologia i zachowanie zgodnie $\mathrm{z}$ europejską polityką badań $\mathrm{i}$ innowacji $\mathrm{w}$ dziedzinie transportu przedstawiono plan działania $\mathrm{w}$ zakresie technologii. Jednym $\mathrm{z}$ celów jest zrównoważona alternatywna strategia $\mathrm{w}$ zakresie paliw, obejmująca również stosowną infrastrukturę. Dokumenty powyższe wyznaczają jednak kierunki rozwoju w zakresie technologii zarówno silników lotniczych, jak i paliw lotniczych, które muszą być dostosowane do możliwości zastosowania ich jako napędu statków powietrznych.

W lotnictwie stosowane są dwa rodzaje paliw silnikowych:

- benzyny lotnicze do tłokowych silników lotniczych;

- paliwa do turbinowych silników lotniczych. 
W eksploatacji statków powietrznych znacznie większe znaczenie ma paliwo do turbinowych silników lotniczych, gdyż stosowane jest obecnie w dominującej ilości samolotów i śmigłowców.

Paliwo lotnicze JET A-1 jest produkowane z komponentów uzyskiwanych $\mathrm{w}$ określonym reżimie technologicznym $\mathrm{w}$ procesach hydroodsiarczania, hydrokrakingu i destylacji. Komponenty odpowiadają ustalonym wymaganiom jakościowym. Paliwo jest uszlachetniane dodatkami uszlachetniającymi (antyutleniającym i antyelektrostatycznym) spełniających wymagania Dokumentu "Turbine Fuel, Aviation Kerosine Type Jet A-1 NATO Code: F35".

\section{Redukcja emisji GHG przez transport lotniczy}

Transport lotniczy to obecnie najszybciej rosnące źródło emisji ditlenku węgla. W okresie 1998-2006 transport lotniczy, generując wzrost z 12,4\% do 14\% ilości zużywanej energii, plasował się na drugim miejscu [2].

Dla Polski, zobowiązanej do inwentaryzacji emisji krajowej gazów cieplarnianych z sektora lotniczego według metodologii 1) IPCC (1997) Revised 1996-IPCC Guidelines for National Greenhouse Gas Inventories Reference Manual IPCC oraz 2) IPCC (2006) 2006-IPCC Guidelinesfor National Greenhouse Gas Inventories, podano w Tablicy 1 dane dotyczące wskaźników emisji [8].

Tablica 1. Wskaźniki emisji GHG z paliw sektora lotniczego

\begin{tabular}{|c|c|c|c|}
\hline Paliwo & $\begin{array}{c}\text { Wskaźnik } \\
\text { emisji CO } \\
{[\mathrm{kg} / \mathrm{GJ}]}\end{array}$ & $\begin{array}{c}\text { Wskaźnik } \\
\text { emisji CH} \\
{[\mathrm{kg} / \mathrm{GJ}]}\end{array}$ & $\begin{array}{c}\text { Wskaźnik } \\
\text { emisji } \mathrm{N}_{2} \mathrm{O} \\
{[\mathrm{kg} / \mathrm{GJ}]}\end{array}$ \\
\hline $\begin{array}{l}\text { Paliwo do turbinowych silników } \\
\text { lotniczych w w lotnictwie } \\
\text { międzynarodowym }\end{array}$ & 73,26 & 0,0005 & 0,0023 \\
\hline $\begin{array}{l}\text { Paliwo do turbinowych silników } \\
\text { lotniczych w w lotnictwie } \\
\text { cywilnym krajowym }\end{array}$ & 73,26 & 0,0005 & 0,0023 \\
\hline Benzyna lotnicza & 72,10 & 0,0600 & 0,0009 \\
\hline
\end{tabular}

Zużycie energii w odniesieniu do benzyn lotniczych i paliwa do turbinowych silników lotniczych w Polsce według [6] w 2007 r. wynosiło odpowiednio 176,00 TJ i 928,80 TJ. Komisja Europejska, mając na uwadze powyższe, już w 1999 r. przygotowała dla Rady Europy, Parlamentu Europejskiego, Komitetu Ekonomiczno-Społecznego i Komitetu Regionów komunikat w sprawie wpływu transportu lotniczego na środowisko naturalne $\mathrm{z}$ propozycjami rozwiązań w zakresie zrównoważonego rozwoju [5]. 
Jednym z rozwiązań jest postulowane przez Unię Europejską ustalenie limitów emisji ditlenku węgla z przelotów, np. na poziomie 2005 r., i stopniowe, rok po roku ich ograniczanie (system cap\&trade). Osiąganie celu nastąpi w pierwszej kolejności poprzez regulację liczby przelotów (cena przelotu), tak aby wielkość ta zapewniła spełnienie ustalonych limitów emisji. Ma to na celu stymulowanie rozwoju technologii silników lotniczych o dwukrotnie niższym spalaniu, co z kolei pozwoli dwukrotnie zwiększyć liczbę przelotów. W następnej kolejności opracowanie silników lotniczych np. z wykorzystaniem ogniw paliwowych może prowadzić do przywrócenia nieograniczonej możliwości przelotów bez negatywnego wpływu na środowisko, $\mathrm{z}$ jednoczesną zmianą procesów przemysłowych i energetycznych, które odpowiadają za znaczą część emisji związanej z budową samolotów i utrzymaniem infrastruktury. Przyjęty przez Parlament Europejski pakiet klimatyczny obejmuje dyrektywę RED (Dyrektywa 2009.28/WE), która dotyczy trzech sektorów gospodarki: produkcji energii elektrycznej, ciepłownictwa oraz transportu $[3,10]$. Państwa członkowskie same decydują o tym, jaki wkład będą mieć poszczególne sektory w osiągnięciu ogólnego celu $20 \%$ udziału, ale sugeruje się, aby państwa członkowskie zapewniły 10-proc. udział energii odnawialnej w sektorze transportowym do 2020 r. Przegląd systemu ETS wprowadzonego dyrektywą 2003/87/ EC [7] w stosunku do sektora lotniczego wskazuje, że od 2012 r. system ten obejmie również emisję ditlenku węgla generowaną przez samoloty lotnictwa cywilnego. To oznacza, że linie lotnicze realizujące loty na terenie Europy oraz do i z Europy będą zobowiązane do uzyskania uprawnień na emisje wygenerowane podczas tych lotów. Wykorzystanie handlu emisjami do zmierzenia się z kwestią szybko rosnących emisji $\mathrm{w}$ transporcie lotniczym jest $\mathrm{w}$ pełni zgodne $\mathrm{z}$ międzynarodowymi zobowiązaniami UE oraz $\mathrm{z}$ decyzjami podjętymi na zgromadzeniu Międzynarodowej Organizacji Lotnictwa Cywilnego w 2004 r.

$\mathrm{W}$ odniesieniu do paliw lotniczych pierwsze kroki w zakresie ograniczania emisji szkodliwych składników $\mathrm{z}$ transportu lotniczego $\mathrm{w}$ UE podjęto $\mathrm{w}$ stosunku do paliwa lotniczego Jet A. Komisja Europejska wraz $\mathrm{z}$ Airbusem i przedstawicielami lotnictwa cywilnego oraz producentów biopaliw zainicjowali działanie pod nazwą Europejska Droga Wykorzystania Biopaliw w Lotnictwie (Launch of the European Advanced Biofuels Flightpath) [1,9]. Jego zadaniem jest wprowadzenie do lotnictwa biopaliw węglowodorowych i osiągnięcie zużycia $2 \mathrm{mln}$ ton/rok w $2020 \mathrm{r}$.

W tym celu konieczne jest połączenie sił w tworzeniu właściwych i skutecznych mechanizmów finansowych, by wesprzeć budowę zaawansowanych, innowacyjnych przemysłowych zakładów produkcji biopaliw. Akcja koncentruje się na następujących zagadnieniach:

- ułatwianiu postępu w normalizacji dla rozwijanych biopaliw i ich certyfikacji do użytku w komercyjnych samolotach;

- współpracy całego łańcucha dostaw w celu dalszego rozwoju powszechnie przyjętych ram certyfikacji zrównoważonego rozwoju; 
- uzgodnieniu systemu logistyczno- ekonomicznego wprowadzania biopaliw w określonym czasie;

- promowaniu odpowiednich publicznych i prywatnych działań w celu zapewnienia wprowadzania na rynek parafinowych biopaliw w sektorze transportu lotniczego;

- ustanowieniu struktury finansowania przedsięwzięć w celu ułatwienia realizacji projektów biopaliw drugiej generacji $(2 \mathrm{G})$;

- przyspieszeniu badań i innowacji;

- ukierunkowanych na zaawansowane technologie związane z biopaliwami, a zwłaszcza związanych z wykorzystaniem alg;

- podjęciu działań w celu informowania obywateli europejskich o korzyściach z zastępowania paliwa naftowego przez certyfikowane, zrównoważone biopaliwa.

Metody pracy i zarządzania zawarto w Strategicznym Planie Technologii Energetycznych (SET-P) Unii Europejskiej, przedstawionym przez Komisję i zatwierdzonym przez Parlament Europejski oraz szefów państw i rządów 4 lutego $2011 \mathrm{r}$.

\section{Technologie konwersji biomasy do biokomponentów/biopaliw węglowodorowych}

Biopaliwa do turbinowych silników lotniczych staną się w niedalekiej przyszłości produktem rynkowym, obecnym na lotniskach cywilnych i wojskowych, również w Polsce.

Kierunek badań prowadzonych przez czołowe w świecie firmy lotnicze wskazuje, że biopaliwami stosowanymi w lotnictwie będą biowęglowodory - komponenty węglowodorowe otrzymywane $\mathrm{z}$ biomasy. Biokomponenty te pod względem budowy chemicznej są zbliżone do paliw otrzymywanych z ropy naftowej, jednak ich własności różnią się od własności stosowanych dotychczas paliw mineralnych. Dlatego też uznano, że sam fakt spełnienia przez mieszanki paliwa mineralnego i komponentu biowęglowodorowego wymagań normatywnych dla paliwa Jet A1 jest niewystarczający, aby dopuścić takie biopaliwo do stosowania w silnikach lotniczych. Stąd firmy lotnicze, mające już pewne osiągnięcia we wdrażaniu biopaliw prowadzą badania na poziomie laboratorium, hamowni silnikowej oraz eksploatacji w rzeczywistych silnikach w próbach naziemnych i w locie.

$\mathrm{W}$ rezultacie takich badań dopuszczone może być do stosowania w określonym typie silnika biopaliwo o określonym składzie chemicznym i wynikających z niego właściwościach. Dopuszczający do stosowania zakłada, że w toku produkcji przemysłowej biokomponentów ich skład chemiczny będzie stabilny. Stabilność składu i właściwości biokomponentów węglowodorowych zależna jest od rodzaju i jakości surowców biomasowych oraz od technologii ich konwersji do komponentów biowęglowodorowych. Dlatego dopuszczający biopaliwo do stosowania w silnikach lotniczych określa nie tylko wymagane właściwości 
biopaliwa, ale również określa rodzaj i jakość surowca biomasowego oraz technologię jego konwersji do biokomponentu paliwa lotniczego.

W wyniku przeprowadzonych badań mających na celu pozyskanie wiedzy teoretycznej w zakresie możliwości stosowania biopaliw w lotnictwie stwierdzono, że technologiami o największej przydatności do wytwarzania biopaliw dla lotnictwa są: synteza Fischera - Tropscha, technologia HVO i polimeryzacja biobutanolu.

Zanalizowano dostępność w Polsce surowców biomasowych do produkcji biokomponentów / biopaliw dla lotnictwa przy zastosowaniu tych technologii. W wyniku analizy stwierdzono, że potencjalnymi surowcami są:

- rzepak (produkcja RME i biowęglowodorów technologią HVO) - zakładając zużycie na cele spożywcze na stałym poziomie do 2020 roku krajowe rolnictwo może dostarczyć (2300 tys. $\mathrm{t}-1100$ tys. $\mathrm{t})+1200$ tys. $\mathrm{t}=2400$ tys. $\mathrm{t}$ ziarna rzepaku na produkcję RME oraz jako surowca do procesu współuwodornienia.

- drewno i odpady drewna (technologia Fischera - Tropscha) - potencjał drewna i odpadów drewna oraz tzw. drewna poużytkowego jest trudny do oszacowania; według KPD na cele energetyczne może być wykorzystane około 560 tys. t odpadów drewna i około 2800 tys. t drewna poużytkowego; zaznaczyć należy, że w konsumpcji drewna i odpadów drewna bardzo silną konkurencję stanowi energetyka (współspalanie $\mathrm{z}$ węglem + ,zielone certyfikaty"); w strategii MRiRW biomasa drzewna nie jest uwzględniana jako surowiec energetyczny - zakłada się zastępowanie w energetyce biomasy drzewnej produktami rolniczymi.

- słoma (technologia Fischera - Tropscha) - ocena zasobów słomy, a zwłaszcza prognozy jej wykorzystania na cele energetyczne są bardzo zróżnicowane; nadwyżka do wykorzystania na cele energetyczne według KPD wynosi $4,8 \mathrm{mln} \mathrm{t}$.

- uprawy energetyczne - aktualnie uprawy energetyczne pozostają na poziomie doświadczalnym areał około 10 tys. ha;

\section{Założenia do programów badawczo - wdrożeniowych w zakresie stosowania biopaliw w lotnictwie}

Przedstawiona powyżej analiza wskazuje na potrzebne dla polskiego przemysłu paliwowego i sektora transportu lotniczego kierunki badań, które może i powinien prowadzić ITWL.

W ramach badań prowadzonych w ITWL opracowana powinna być szczegółowa koncepcja wprowadzenia do lotnictwa cywilnego i Sił Zbrojnych RP biopaliw do turbinowych silników lotniczych. Opracowany powinien być algorytm postępowania przy wyborze rodzaju wdrażanych do lotnictwa biopaliw, badania właściwości eksploatacyjnych wybranych biopaliw na poziomie laboratoryjnym, opracowanie wstępnych wymagań dla wybranych biopaliw, weryfikacja wymagań eksploatacyjnych wybranych biopaliw w testach silnikowych. 
Opracowany algorytm postępowania pozwoli na planowanie projektów badawczych ITWL, stanowiących element spójnej polityki wdrażania biopaliw w Siłach Zbrojnych RP, zgodnie z polityką NATO oraz uwarunkowaniami w lotnictwie cywilnym i w sektorze paliwowym.

$\mathrm{Na}$ tej podstawie określona będzie strategia prac badawczych i wdrożeniowych realizowanych przez ITWL w zakresie biopaliw dla lotnictwa, koniecznych ze względu na bezpieczeństwo lotów oraz wkład ITWL do określenia polityki Rządu RP w zakresie redukcji emisji $\mathrm{CO}_{2}$ w lotnictwie.

$\mathrm{Na}$ obecnym etapie proponowane jest podjęcie następujących badań:

- Wybór, na podstawie wyników badań wykonanych w 2013 r., technologii wytwarzania biokomponentów do paliw dla turbinowych silników lotniczych, preferowanych ze względu na dostępność surowców i jakość produktu.

- Określenie, na podstawie danych literaturowych i kontaktów bezpośrednich z zagranicznymi wytwórcami biokomponentów węglowodorowych składu chemicznego wybranych biokomponentów i zakresu jego zmienności.

- Opracowanie reprezentatywnego dla wybranych technologii składu chemicznego modeli biokomponentów i wykonanie ich w laboratorium.

- Przygotowanie mieszanek modeli biokomponentów z paliwem Jet A1 i badania ich własności fizykochemicznych.

- Badanie wybranych mieszanek modeli biokomponentów i Jet A1 w testach silnikowych.

Prowadzenie testów silnikowych $\mathrm{w}$ aspekcie stosowania alternatywnych paliw na hamowni rzeczywistego turbinowego silnika lotniczego jest bardzo kosztowne. Dlatego po weryfikacji nowego paliwa w zakresie własności fizykochemicznych w laboratorium, korzystnie jest przeprowadzić pośrednie testy hamowniane na modelowych silnikach odrzutowych.

Badania tego typu mogą być realizowane na stanowisku hamownianym miniaturowego turbinowego silnika lotniczego, które jest aktualnie budowane w Zakładzie Materiałów Pędnych i Smarów ITWL. Zasadniczym elementem całego stanowiska jest modelowy turbinowy silnik odrzutowy serii GTM (Rys. 3).

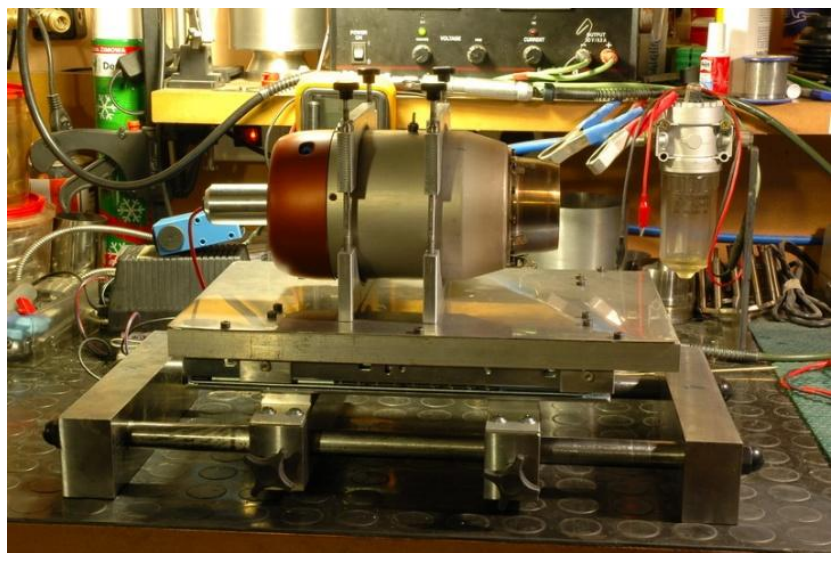

Rys. 3 Miniaturowy silnik odrzutowy serii GTM [11] 
Charakteryzuje się on pracą z zakresie 33-120 tys. obr/min. oraz maksymalnym ciągiem o wartości $140 \mathrm{~N}$. Zbudowany jest w oparciu o jednostopniową sprężarkę promieniową, napędzaną jednostopniową turbiną osiową oraz pierścieniową komorę spalania wraz z zestawem parownic. Sterowanie pracą silnika odbywa się poprzez mikroprocesorowy kontroler z panelu wyświetlacza LCD. Na stanowisku pomiarowym miniaturowego silnika odrzutowego istnieje możliwość pomiaru podstawowych parametrów pracy silnika: siły ciągu, zużycia paliwa, prędkości obrotowej oraz temperatury gazów wylotowych. Oprócz badań realizowanych na stanowisku hamownianym związanych bezpośrednio z pomiarami parametrów pracy silnika, będzie istniała możliwość wykonania również badań emisji spalin oraz pomiarów wielkości cząstek stałych. W zakresie badań emisji spalin możliwe będzie wykonanie pomiarów stężeń: $\mathrm{CO}, \mathrm{CO}_{2}, \mathrm{NO}, \mathrm{NO}_{2}, \mathrm{C}_{\mathrm{x}} \mathrm{H}_{\mathrm{y}}$ oraz $\mathrm{SO}_{2}$.

\section{Wnioski}

1. W wyniku przeprowadzonych badań mających na celu pozyskanie wiedzy dotyczącej prawnych i standaryzacyjnych uregulowań odnoszących się do wprowadzania biopaliw do lotnictwa stwierdzono, że:

- aktywność UE w realizacji idei zrównoważonego rozwoju i troska o środowisko naturalne znajduje odzwierciedlenie w ustanawianych przez Parlament Europejski i Radę Europy dyrektywach.

- w odniesieniu do paliw lotniczych pierwsze kroki w zakresie ograniczania emisji szkodliwych składników $\mathrm{z}$ transportu lotniczego w UE podjęto w stosunku do paliwa lotniczego Jet A. Komisja Europejska wraz z Airbusem i przedstawicielami lotnictwa cywilnego oraz producentów biopaliw zainicjowali działanie pod nazwą Europejska Droga Wykorzystania Biopaliw w Lotnictwie (Launch of the European Advanced Biofuels Flightpath). Jego zadaniem jest wprowadzenie do lotnictwa biopaliw węglowodorowych i osiągnięcie zużycia $2 \mathrm{mln}$ ton/rok w $2020 \mathrm{r}$.

2. W wyniku przeprowadzonych badań mających na celu pozyskanie wiedzy teoretycznej w zakresie możliwości stosowania biopaliw w lotnictwie stwierdzono, że:

- technologiami o największej przydatności do wytwarzania biopaliw dla lotnictwa są: synteza Fischera - Tropscha, technologia HVO i polimeryzacja biobutanolu;

- dostępność surowców biomasowych dla w/w technologii jest w Polsce ograniczona ze względu na wymóg stabilności rodzaju i jakości tych surowców.

\section{Literatura}

[1] 2 million tons per year: A performing biofuels supply chain for EU aviation, 2011.

[2] 2008 Environment Policy Review, European Communities, 2009. 
[3] Antosz A., Syrek H.: Emisje gazów cieplarnianych w procesach wydobycia i transportu ropy naftowej, Nafta-Gaz, 2012, s. 233-240.

[4] BIAŁA KSIĘGA. Plan utworzenia jednolitego europejskiego obszaru transportu - dążenie do osiągnięcia konkurencyjnego i zasobooszczędnego systemu transportu, Komunikat (2011) 144 Komisji Europejskiej z 28.03.2011r.

[5] Communication from the Commission to the Council, the European Parliament, the Economic and Social Committee and the Committee of the Regions. Air Transport and the Environment, Towards meeting the Challenges of Sustainable Development, Brussels, 1.12.1999 COM (1999) 640 final.

[6] Dębski B.: Inwentaryzacja emisji krajowej gazów cieplarnianych z lotnictwa, Zespół Krajowego Centrum Inwentaryzacji Emisji, Warszawa 2009.

[7] Dyrektywa 2003/87/WE Parlamentu Europejskiego i Rady z dnia 13 października 2003 r. ustanawiająca system handlu przydziałami emisji gazów cieplarnianych we Wspólnocie oraz zmieniająca dyrektywę Rady 96/61/WE.

[8] Działania UE przeciw zmianom klimatu. Europejski System Handlu Emisjami (ETS), Komisja Europejska, 2009.

[9] Launch of the European Advanced Biofuels Flightpath.

[10] Syrek H., Rogowska D.: Development of refining industry and reduction of greenhouse gas emission, Nafta-Gaz, 2011, s. 474-482.

[11] Materiały firmy JETPOL wykonującej małe silniki turboodrzutowe.

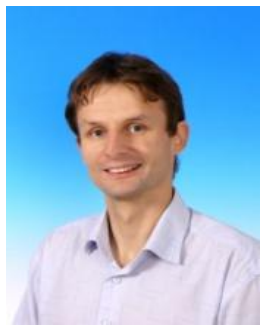

dr inz. Bartosz Gawron - absolwent Wojskowej Akademii Technicznej na kierunku mechatronika, specjalność: samoloty $i$ śmiglowce, $w$ latach 2008-2012 doktorant na studiach III stopnia w WAT na Wydziale Mechatroniki $i$ Lotnictwa, od 09.2012 doktor nauk technicznych $w$ dyscyplinie naukowej mechanika. Aktualnie pracownik naukowy w Instytucie Technicznym Wojsk Lotniczych.

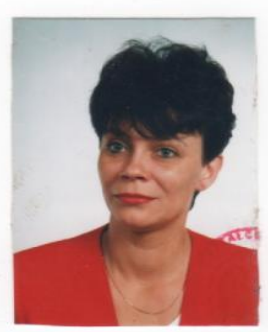

mgr Urszula Kaźmierczak - od 1993 r. zatrudniona była $w$ Centralnym Laboratorium Naftowym, przekształconym w 2006 r. w Instytut Paliw i Energii Odnawialnej. W 2007 roku objęta stanowisko dyrektora Instytucji Wdrażajacej POIiŚ. Obecnie jest zatrudniona $w$ Instytucie Technicznym Wojsk Lotniczych, gdzie zajmuje się zagadnieniami zrównoważonego rozwoju, w tym biopaliwami. 